\title{
Afektywne dostrojenia i sprawczość w czasach późnego industrializmu
}

\section{Abstract}

\section{Affective Attunements and Agency in Late Industrialism}

The article explores the context of the expansion of Opole Power Plant, which has fuelled new migration patterns in the region of Dobrzen Wielki. By drawing on the ethnographic fieldwork among construction workers working at the expansion site and living temporarily in the region, it aims to problematise the relationship between their mobile livelihood, agency and affective attunements. It argues that the emergence of late industrialism, which coincided with the neoliberal reconfigurations of global political economy, has produced different modes of uncertainties, forced flexibilities and rather bleak futures. Consequently, for many construction workers, whose livelihood chiefly depends on mobility between different industrial sites in Poland, the contemporary global entanglements create a "charged atmosphere", which has to be negotiated and acted upon in different ways.

Keywords: mobility, affects, attunements, agency, late industrialism.

\section{Wprowadzenie}

W dyskursie publicznym inwestycje rozwojowe zazwyczaj postrzegane są w kategoriach ważności i przydatności ${ }^{1}$. Są wręcz pożądane ekonomicznie i traktowane jako siła napędowa procesów modernizacyjnych, jako motor postępu społeczeństwa oraz główny cel ekonomii politycznej państwa. Tego rodzaju podejście często pozbawione jest jednak zniuansowanej, kontekstualnej i zlokalizowanej wiedzy

1 Artykuł powstał w wyniku realizacji projektu badawczego pod tytułem Konflikt, napięcie, współpraca. Studium interakcji pomiędzy Elektrowniq̨ Opole a społecznościa gminy Dobrzeń Wielki (nr DEC-2013/11/B/HS3/03895) finansowanego ze środków Narodowego Centrum Nauki. 
na temat sposobów „działania” takich inwestycji oraz ich „wpływu” zarówno na dane społeczności, jak i aktorów społecznych biorących w nich udział. Z perspektywy antropologicznej relacje te nie są jednostronne, ale raczej wielowymiarowe, różnorodne i często pociągają za sobą niezamierzone konsekwencje (zob. Larkin 2013). Z pewnością jednak inwestycje rozwojowe to interesujący teren etnograficznych dociekań, w którym globalne siły rozgrywane są w lokalnych światach. Wyłania się więc kontekst rozmaitych tarć, napięć, ale także i współpracy, które razem przekształcają dane społeczności i sytuują aktorów społecznych w globalnych scenariuszach działań. Thomas Hylland Eriksen (2016: 16) zauważa, że tego rodzaju zależności i transformacje ukazują złożoną dynamikę, w ramach której „ludzie na całym świecie zmuszeni są renegocjować swoje strategie ekonomiczne czy też prawo do definiowania tego, kim są, co w warunkach presji może wręcz prowadzić do kryzysów tożsamościowych". Inwestycje rozwojowe uruchamiają więc różnego rodzaju formy negocjowania zastanego porządku i antycypowania przyszłych zdarzeń.

Przeobrażenia ekonomii politycznej zachodzące w ciągu ostatnich kilkudziesięciu lat odegrały istotną rolę $\mathrm{w}$ sposobach negocjowania tego, co globalne i lokalne. Innymi słowy, przejście od kapitalizmu „zorganizowanego” (Lash, Urry 1987) do kapitalizmu „późnego” (czy też „neoliberalnego”) (zob. Harvey 2008; Ong 2006; por. Wacquant 2012) znacząco zredefiniowało nie tylko funkcje i cele gospodarcze, ale także rolę państwa i społeczeństwa w procesach ekonomicznych. Koniec kapitalizmu „zorganizowanego” oznaczał bowiem koniec klasycznego "porządku przemysłowego" i przejście do epoki postfordyzmu, w której relacja między pracą a kapitałem stała się elastyczna, a wartość samej pracy często po prostu „zbędna”. Jak pisze Zygmunt Bauman:

fordyzm był samoświadomością nowoczesnego społeczeństwa w jego „ciężkiej” i „masywnej” czy też „nieruchomej” i „ukorzenionej” - „stałej” fazie. Na tym etapie swojej wspólnej historii kapitał, przedsiębiorcy i pracownicy skazani byli na to, by w przewidywalnej przyszłości, a może nawet na zawsze pozostawać ze sobą w związku, za sprawą współistnienia olbrzymich budynków fabrycznych, ciężkich maszyn produkcyjnych i masowej siły roboczej (Bauman 2006: 88).

Tym samym kapitalizm w wersji ciężkiej „był ogarnięty obsesją wielkości i masywności, a co za tym idzie, także obsesją granic, obsesją ich umacniania i uszczelniania" (Bauman 2006: 89). Inaczej natomiast wygląda to we współczesnej formie kapitalizmu, w ramach której „kapitał przemieszcza się bez trudu i bez zbędnych obciążeń: wyłącznie z bagażem podręcznym, który składa się z aktówki, telefonu komórkowego i laptopa" (Bauman 2006: 90). To raczej zysk, a nie praca, okazał się rdzeniem neoliberalnej wersji systemu kapitalistycznego. Industrialny „porządek" fordyzmu został więc zastąpiony przez rynkową deregulację, prywatyzację i spekulacje.

Wraz z neoliberalną formą kapitalizmu nastały również czasy większej niepewności i ryzyka (Beck 2002; Giddens 2007; Sennett 2010; Samimian-Darash, Rabinow 2015), które Kim Fortun $(2012,2014)$ nazywa czasami „późnego indu- 
strializmu”. Jest to kontekst „modernistycznego bałaganu” - wyłaniania się często niezamierzonych konsekwencji wcześniej obowiązującej „industrialnej teorii znaczenia i wartości” oraz „industrialnej ideologii językowej”, która wytworzyła określone „nawyki umysłu, języka, budowania i regulacji w porządku industrialnym uprzywilejowującym produkcję, produkty i własność” (Fortun 2014: 312-313). Neoliberalizm i późny industrializm sprawiają, że przyszłość staje się niepewna, a w niektórych przypadkach nawet niebezpieczna i zagrażająca życiu (Fortun 2001). Podczas gdy neoliberalna rekonfiguracja ekonomii politycznej rozluźnia stabilność utrzymania środków do życia i wprowadza zorientowaną na zyski „akumulację przez wywłaszczenie”, atmosfera późnego industrializmu wywołuje obawy związane z warunkami pracy i kwestiami bezpieczeństwa. Łącznie tworzą one „naładowaną atmosferę" (Stewart 2011), w której to, co globalne, nieustannie przenika się z tym, co lokalne. Codzienność w późnym industrializmie to zatem kontekst, w którym „dyskursy emocjonalne i ekonomiczne oraz praktyki kształtują siebie nawzajem”, co sprawia, że „afekty stanowią istotny aspekt zachowań ekonomicznych" (Illouz 2010: 10-11).

Jest to istotny kontekst zależności, który wyłonił się w ramach prowadzonych przeze mnie badań etnograficznych dotyczących migracji i mobilności pracowników budowlanych, a będących rezultatem wielkiej inwestycji rozwojowej, jaką jest rozbudowa Elektrowni Opole. Sama elektrownia i jej wpływ na społeczność lokalną gminy Dobrzeń Wielki były już przedmiotem wielu badań i analiz (zob. Rauziński 1988; Łuszczewska 1993; Lesiuk, Rauziński i Sołdra-Gwiżdż 2000; Rosik-Duleska, Kusza 2009; Sołdra-Gwiżdż 2009). Budowa Elektrowni Opole trwała od 1973 roku, kiedy to podjęto decyzję o jej wybudowaniu, do 1993 roku, kiedy to została ostatecznie otwarta. Sama budowa uruchomiła znaczące procesy migracyjne, w ramach których do gminy Dobrzeń Wielki (i Opola) przyjechali wówczas liczni inżynierowie, elektrycy i pracownicy budowlani z różnych stron Polski. Wielu z nich zostało, sprowadziło swoje rodziny i dziś są już silnie zakorzenieni w tkance społeczności lokalnej. Niemniej plan budowy elektrowni spotkał się początkowo z licznymi obawami ze strony mieszkańców. Kontekst migracji i wpływ elektrowni na środowisko naturalne gminy postrzegane były wówczas w sposób podejrzliwy. $Z$ czasem jednak obawy te zaczęły sukcesywnie ustępować, a sama elektrownia zyskała status neutralnej, a nawet i pożądanej infrastruktury, która odgrywa pozytywną rolę w społeczności lokalnej².

2 Współcześnie elektrownia jest niezwykle istotnym elementem w krajobrazie społecznym, kulturowym, ekonomicznym i politycznym społeczności lokalnej. To dzięki elektrowni gmina Dobrzeń Wielki stała się jednym z najbogatszych regionów w Polsce z bardzo niską stopą bezrobocia. Pozytywny stosunek do elektrowni można również zauważyć w kontekście reakcji mieszkańców na zmiany administracyjne wprowadzone w 2017 roku przez władzę państwową. Kiedy przeprowadzałem badania w 2015 i 2016 roku, elektrownia położona we wsi Brzezie administracyjnie wchodziła w skład gminy Dobrzeń Wielki. Jednak 1 stycznia 2017 roku, wbrew woli mieszkańców, gmina została podzielona, a duża część wsi Brzezie, w tym elektrownia, została administracyjnie przydzielona do Opola. Była to decyzja odgórna i jednoznacznie polityczna, która spotkała się z silnym sprzeci- 
Rozbudowa bloku 5. i 6. Elektrowni Opole, która rozpoczęła się w 2014 roku, uruchomiła nowe konteksty migracyjne w społeczności lokalnej ${ }^{3}$ Ta jedna z największych, finansowanych przez państwo, inwestycji w Europie przyciągnęła bowiem nowych pracowników budowlanych oraz specjalistów z różnych części Polski (a także z Ukrainy czy Białorusi). W latach 2015-2016, kiedy prowadziłem badania, przez plac budowy przewinęło się kilkanaście tysięcy pracowników budowlanych zatrudnianych przez rozmaite firmy z różnych części Polski. Większość $\mathrm{z}$ nich pozostawała $\mathrm{w}$ regionie jedynie tymczasowo, będąc zakontraktowanymi do wykonania określonych zadań. Tego rodzaju tymczasowość trwała od kilku do kilkunastu miesięcy, co sprawiało, że codzienność i mobilne praktyki pracowników budowlanych okazały się niezwykle interesującymi przykładami strategii ekonomicznych, charakterystycznych dla neoliberalnej formy kapitalizmu, w której dominują elastyczność i niestabilność.

W artykule skupiam się na kontekście rozbudowy Elektrowni Opole, który uruchomił nowe procesy migracyjne w gminie Dobrzeń Wielki. Wychodząc od badań etnograficznych przeprowadzonych wśród pracowników budowlanych zatrudnionych przy rozbudowie elektrowni i przebywających na terenie gminy tymczasowo, problematyzuję relacje pomiędzy mobilnymi strategiami ekonomicznymi pracowników budowlanych, ich sprawczością i afektywnymi dostrojeniami w kontekście późnego industrializmu.

\section{Etnografia w późnym industrializmie}

Rozbudowa Elektrowni Opole to specyficzny teren problematyzacji antropologicznych. Z jednej strony jest on zamknięty i ograniczony fizycznie w dosłownym tego słowa znaczeniu. Z łatwością można więc wytyczyć jego „widzialne” granice, używając do tego markerów, jakimi są skrupulatnie rozplanowana infrastruktura industrialna, hałdy węgla czy też liczne znaki ostrzegawcze i zakazu wstępu. $\mathrm{Z}$ drugiej jednak strony, wychodząc poza geograficzne rozumienie przestrzeni, na terenie elektrowni można wskazać również różnego rodzaju przecięcia pomię-

wem społeczności lokalnej. W 2016 roku zaczęły się liczne demonstracje w Dobrzeniu Wielkim i Opolu, których celem było utrzymanie jedności gminy. Mieszkańcy organizowali również konsultacje społeczne i spotkania eksperckie, pisano listy i petycje do władz z żądaniem zatrzymania zaplanowanych zmian granic administracyjnych. Zdaniem wielu mieszkańców, była to „aneksja” mająca podłoże polityczne i ekonomiczne związane z podatkiem generowanym przez elektrownię.

3 Opolszczyzna często określana jest w literaturze przedmiotu jako „region emigracyjny”, mający bliskie powiązanie transnarodowe z Niemcami, które są głównym celem migracji zarobkowej Polaków tam mieszkających. Wielu badaczy reprezentujących różne perspektywy badawcze (socjologia, demografia i ekonomia) wskazuje na silne związki pomiędzy migracją a procesami społeczno-ekonomicznymi regionu, takimi jak poziom bezrobocia, transmisja kapitału, przedsiębiorczość czy też inwestycje na lokalnym rynku (zob. Jończy 2003, 2006, 2010; Heffner, Rauziński 2012; Heffner, Solga 2009; Solga 2009). 
dzy skalą lokalną, narodową i globalną. W konsekwencji ulega on znaczącemu poszerzeniu i wprowadza kontekst, w którym rozgrywane są rozmaite zależności i powiązania charakterystyczne dla współczesności (Fortun 2012; Rabinow i in. 2008). Zatem rozbudowa Elektrowni Opole to nie tylko plac budowy, ale także przestrzeń przenikania się różnych strategii, praktyk i wyobrażeń, które wychodzą daleko poza fizyczność miejsca.

Tego rodzaju podejście przypomina oczywiście o tym, że „badania etnograficzne nie są już tym, czym były” (Faubion, Marcus 2009), a kategoria „terenu” w antropologii uległa licznym przeobrażeniom, relokacjom i poszerzeniom (zob. Amit 2000; Gupta, Ferguson 1997a; Gupta, Ferguson 1997b; Olwig, Hastrup 1997). W klasycznej antropologii teren postrzegano jako zamkniętą przestrzeń fizyczną z silnie wyznaczonymi granicami, którą należy eksplorować w oderwaniu od wpływów i procesów globalnych (zob. Pawlak 2018: 19-23). Teren utożsamiano więc z „autentycznością" i „egzotyką", a wszelkie aspekty globalizacji traktowano jako "siłę niszczycielską" i kulturową zbrodnię przeciwko „prawdziwej” kulturze. Klasyczna antropologia „więziła” wręcz badane społeczności (Tsing 2002: 465), „zakorzeniając” ich tożsamości w geograficznych przestrzeniach i niejako zamrażając je w czasie za pomocą statycznych opisów opartych na dwóch podstawowych modelach - „ratunkowym” i „zbawiennym” (Marcus 1986: 165-166).

Istniejące zależności pomiędzy globalną ekonomią, polityką a lokalnością nie mogą zatem być po prostu opisane w klasycznych ramach etnograficznych, w których teren konceptualizowany był jako zamknięty i hermetyczny. Współczesność charakteryzuje się raczej dynamiką i zmianą, co sprawia, że badania etnograficzne w swej definicji są wielowymiarowe, wielostanowiskowe i osadzone w różnych reżimach dyskursów i praktyk (zob. Holmes, Marcus 2006; por. Ong, Collier 2005; Olwig, Hastrup 1997). Nie oznacza to jednak, że „lokalność”, „kultura” czy „region" straciły swe znaczenie. Wręcz przeciwnie, ciągle pozostają one istotnymi przestrzeniami działań społecznych, takich jak negocjowanie globalnych procesów i zjawisk. Zmianie uległo jednak samo podejście poznawcze do tych kategorii. „Kultury”, „ludzie” i „tożsamości” jako kategorie analityczne przestały być konceptualizowane jako statyczne i nieruchome, a zyskały miano dynamicznych i zależnych od globalnych złożoności i transnarodowych powiązań. Zerwano zatem z ideą odseparowanych i izolowanych „kultur” na rzecz procesów polityczno-ekonomicznych, praktyk społecznych i mobilności znaczeń kulturowych, często łączących z sobą w nierównych relacjach „centra” i „peryferie” (Gupta, Ferguson, 1997b: 2). W rezultacie teren w badaniach etnograficznych przestał więc mieć znamiona tylko i wyłącznie geograficznej lokacji (Gupta, Ferguson, 1997b: 35-40). Nie jest to oczywiście związane z porzuceniem etnografii, ale raczej z poszerzeniem samego rozumienia fizyczności i kontekstów bycia „na miejscu”, w terenie. Mówiąc inaczej, punktem wyjścia współczesnych przedsięwzięć etnograficznych nie jest już „porządek” lokalności i umiejscowione konteksty życia społecznego i kulturowego, ale raczej „nie-porządek” ukazujący dynamikę i relacyjność 
powiązań pomiędzy makro- (globalnymi) a mikro- (lokalnymi) poziomami praktyk społecznych i wyobrażeń kulturowych (Olwig, Hastrup 1997: 7).

Teren rozbudowy elektrowni łączy w sobie tego rodzaju różne przecięcia, skale i konteksty społeczne, kulturowe, polityczne i ekonomiczne. Około dwustu metrów od głównego wejścia do elektrowni znajdował się budynek hotelu, który na czas rozbudowy stał się hotelem robotniczym zamieszkiwanym przez tymczasowych pracowników budowlanych z różnych regionów Polski, Ukrainy i Białorusi. Spędziłem tam miesiąc na obserwacji, rozmowach i „towarzyszeniu” (Rabinow 2011) pracownikom budowlanym w ich czasie wolnym i odpoczynku pomiędzy zmianami w pracy. Był to krótki, aczkolwiek intensywny czas terenowy, który ujawnił dużą mobilność i przetasowania pracowników. Wielu z nich przyjeżdżało jedynie na chwilę, aby wykonać zlecone zadanie, a po ich wyjeździe przyjeżdżali nowi. Byli też jednak tacy, którzy mieszkali w hotelu przez kilka miesięcy. Mobilność $\mathrm{w}$ hotelu w dużej mierze zależała więc od tempa prac prowadzonych przy rozbudowie bloków elektrowni. W konsekwencji sam hotel okazał się niezwykle interesującą przestrzenią wytwarzania tymczasowych codzienności i praktyk spędzania czasu pomiędzy pracą na budowie. Była to także przestrzeń specyficzna w sensie fizycznym, raczej odizolowana od innych budynków mieszkalnych, otoczona industrialnym krajobrazem i infrastrukturą. Poza kilkudziesięcioma pokojami (moduły dwu- i czteroosobowe z łazienką) zamieszkiwanymi przez pracowników budowlanych, a opłacanymi przez zatrudniające ich firmy, na parterze znajdowała się również restauracja $\mathrm{z}$ barem oraz sala gier $\mathrm{z}$ „jednorękimi bandytami”, stołem bilardowym, „piłkarzykami” i konsolą do gier wideo. W hotelu pracowały głównie kobiety (kucharki, sprzątaczki, barmanki, recepcjonistki), a większość z nich pochodziła z Ukrainy.

Pracownicy budowlani, z którymi rozmawiałem na tematy mobilności i wyjazdów „za pracą”, pochodzili głównie z Mazowsza, Śląska, Małopolski i Podkarpacia. W hotelu mieszkali więc sąsiedzi z jednej z małopolskich wsi, a nawet i rodziny (kuzyni, teść i zięć). Pracownicy z Ukrainy i Białorusi tworzyli własne grupy, ale nie dochodziło do konfliktów z polskimi pracownikami ${ }^{4}$. Czasem pojawiała się jedynie „krytyka” ze strony Polaków, że Ukraińcy pracują zbyt ciężko, co sprawia, że polscy budowlańcy sprawiają wrażenie „leniwych”. Większość z nich zatrudniona była w małych lub średnich prywatnych firmach budowlanych, które pełniły rolę podwykonawców zatrudnianych do określonych prac przez firmę Mostostal pełniącą funkcję głównego wykonawcy robót i nadzorującą całą rozbudowę elektrowni. Moi informatorzy pracowali jako zbrojarze, spawacze i stolarze, ale w hotelu spotkać można było również inżynierów, którzy często po pracy

${ }_{4}$ O pojawiających się konfliktach dowiadywałem się jedynie z opowieści pracowników budowlanych, aczkolwiek nie były to konflikty pomiędzy Polakami a Ukraińcami, lecz pomiędzy samymi Polakami pochodzącymi z różnych regionów kraju. Na przykład od kilku osób (w tym pracowników hotelu) słyszałem o ostrym sporze pomiędzy Warszawą a Radomiem. Niemniej z narracji wynika także, że były to raczej sporadyczne incydenty. 
odwiedzali bar, czekając na transport do Opola, gdzie byli zakwaterowani. Praca budowlańców miała charakter zmianowy (także „dniówki” i „nocki”) i trwała niekiedy po 12 godzin, od poniedziałku do piątku (a często i w soboty, w zależności od postępu prac na budowie). Specyfika pracy oraz położenie hotelu wprowadzały kontekst ograniczonych interakcji ze społecznością lokalną, a jedną z niewielu okazji do spotkań z mieszkańcami gminy były zakupy w pobliskim sklepie Biedronka lub Tesco, które wraz z rozpoczęciem prac rozbudowy elektrowni zostały otwarte w pobliskiej wsi ${ }^{5}$.

Muszę przyznać, że był to trudny teren badawczy pod względem dostępu i początkowych prób nawiązania relacji badawczych. Był to bardzo zmaskulinizowany świat, w ścisłym tego słowa znaczeniu. Ponadto problematyczne, a raczej wzbudzające podejrzenia, okazały się moje próby nawiązywania rozmów na tematy życia mobilnego i pracy w warunkach mobilności. Niemniej, im więcej czasu spędzałem w hotelowej restauracji i sali gier, tym łatwiej i dłużej nam się rozmawiało. Duża w tym zasługa barmanki, Blanki, która pełniła funkcję mojej gatekeeperki, legitymizując mój pobyt w hotelu, zadawanie „dziwnych” pytań czy próby nawiązywania kontaktu. W konsekwencji umożliwiło mi to nie tylko prowadzenie (nienagrywanych) rozmów na temat życiowych doświadczeń pracowników budowlanych, ale także spędzanie z nimi weekendów wolnych od pracy.

\section{Afektywne dostrojenia}

Specyfika terenu (hotelu i placu budowy) oraz intensywna praca zmianowa moich informatorów niosły z sobą poważne problemy poznawcze polegające na początkowych trudnościach $\mathrm{w}$ dostrzeganiu i problematyzowaniu podstawowych wręcz kontekstów antropologicznych. Mówiąc inaczej, ze względu na ograniczoną w sensie fizycznym, jak również temporalnym, codzienność pracowników budowlanych, niezwykle trudno było mi zaobserwować na początku badań jakąkolwiek formę ich sprawczości i negocjowania przez nich własnej pozycji.

Już sam kontekst spędzania czasu wolnego, pomiędzy jedną a drugą zmianą, wydawał mi się początkowo mało sprawczy, a nawet wręcz pasywny. Czy bowiem sprawczością można nazwać grę w bilard, gry wideo lub „jednorękich bandytów”? A to właśnie $\mathrm{w}$ ten sposób większość pracowników budowlanych organizowała swoją codzienność pomiędzy jedną a drugą zmianą na placu budowy. Inni z kolei, po skończonej „robocie”, szli prosto do swoich pokoi, gdzie zajmowali się przy-

5 Kontekst rozbudowy bloku 5. i 6. elektrowni uruchomił liczne, także lokalne, inicjatywy ekonomiczne w gminie, w tym wynajem pokoi gościnnych dla przyjeżdżających pracowników budowlanych. W konsekwencji pracownicy budowlani byli rozproszeni i zamieszkiwali większość wsi w gminie. Niemniej, z relacji mieszkańców wynika, że interakcje z nimi były bardzo ograniczone ze względu na charakter i wymiar ich pracy. Najczęściej dochodziło do nich w sklepach spożywczych, jednak w przypadku innych oferowanych usług (np. gastronomicznych) były one znikome. 
gotowywaniem posiłków, oglądaniem telewizji kablowej lub rozmawiali przez Skypea ze swoimi rodzinami. W weekendy natomiast, kiedy pracy było mniej lub gdy nie było jej w ogóle, część pracowników budowlanych odwiedzała kluby nocne w Opolu, jednak większość z nich wracała na dzień lub dwa do swoich rodzinnych miejscowości, żon i dzieci. Tego rodzaju codzienność wprowadza pewnego rodzaju dyskomfort badawczy, ponieważ jej powtarzalność przesłania konteksty sprawczości. Niemniej, im dłużej przebywałem z moimi informatorami w hotelu i uczestniczyłem w tej powtarzalności, tym częściej zacząłem dostrzegać afektywne elementy takiej codzienności, które implikowały sprawcze strategie i działania w specyficznych warunkach.

Kathleen Stewart $(2005,2007,2011)$ zauważa, że codzienność będąca pewnego rodzaju asamblażem praktyk, wiedzy i znaczeń jest silnie afektywna. Wytwarzamy codzienność za pomocą afektów, jak również doświadczamy jej w sposób afektywny. To właśnie w tego rodzaju codziennych i zwykłych afektach zaobserwować można wyłaniające się konteksty zróżnicowanego działania i oddziaływania, które „nadają naszemu codziennemu życiu jakość nieustannego ruchu relacji, scenerii, zdarzeń losowych i emergencji” (Stewart 2007: 1-2). Mówiąc inaczej, codzienne afekty dotyczą „rzeczy, które po prostu się wydarzają”, i które:

dzieją się w impulsach, przeżyciach, oczekiwaniach, marzeniach, spotkaniach, nawykach, w strategiach i porażkach, w formach perswazji, zarażeń i przymusu, w sposobach przyciągania uwagi, przywiązaniach i sprawczości, jednym słowem - w różnego rodzaju publicznych i społecznych światach, które powodują, że coś staje się czymś (Stewart 2007: 2).

Powtarzalność praktyk i strategii codzienności pracowników budowlanych była czymś, co implikowało kontekst sprawczości, afektywnie wypracowany i zhabituowany w toku wieloletnich doświadczeń. Afektywna codzienność ma wpływ na to, jak ludzie „interpretują zmieniający się świat, pozycjonują się względem innych i kształtują swoje subiektywności” (Svašek 2012: 3; por. Svašek 2005). Co istotne, tożsamościowe „ja” nie jest tu ani „zamkniętym pojemnikiem namiętności, ani też jednostką po prostu reagującą na siły z zewnątrz”; jest raczej „mobilnym, złożonym i relacyjnym byciem-w-świecie", które kształtowane jest w ramach istniejących warunków społecznych i kulturowych, a jednocześnie „zaangażowane w przeszłość, teraźniejszość i przyszłość" (Svašek 2012: 3; zob. także Pawlak 2018: 23-28). Afektywność zmienia także samo rozumienie emocji, które przestają być jedynie indywidualnym „odczuwaniem” - afektywne rozumienie emocji ujawnia ich społeczny, kulturowy, ekonomiczny i polityczny charakter (Clough, Halley 2007). Zatem emocje to nie tylko konteksty znaczeń, ale również relacje władzy i ideologie (Lutz 2017: 187).

W perspektywie afektywnej emocje wyłaniają się bowiem w dynamice dyskursów, praktyk i ucieleśnionych doświadczeń, będących rezultatem procesów i interakcji społecznych (Svašek 2012: 9-13). Dyskursywność emocji ukazuje, w jaki sposób kulturowe kategorie i znaczenia emocji produkują wiedzę o świe- 
cie, danym społeczeństwie i tożsamościowym „ja”, w ramach której wyłaniają się mechanizmy "tworzenia, podtrzymywania lub kwestionowania relacji władzy mających wpływ na podmiotowość" (Svašek 2012: 9). Perspektywa skierowana na praktyki emocjonalne wprowadza $\mathrm{z}$ kolei kontekst „performatywnej natury emocji” rozumianej w znaczeniu zarówno „nieświadomych”, zhabituowanych i „wyuczonych” praktyk społeczno-kulturowych, jak i „intencjonalnej polityki emocji" (Svašek 2012: 10-11). Emocje postrzegane natomiast jako ucieleśnione doświadczenia pokazują, $\mathrm{w}$ jaki sposób emocjonalność nadaje podmiotowości ciała i samej cielesności funkcje społeczne, znaczenia kulturowe i role polityczne (Svašek 2012: 11-13; por. Pawlak 2018). Afektywność emocji ukazuje nie tylko ich „znaczenie”, ale także „wpływ” na praktyki codzienności.

Emocje wywołane są za sprawą multisensorycznego bycia w świecie, a więc są one wpisane w strategie podejmowanych przez nas działań i sposobów doświadczania świata. Ukazują one czasowe i przestrzenne złożenia, które mają duży wpływ na praktyki społeczne i wytwarzane znaczenia kulturowe. Afektywność emocji pozwala eksplorować dialektykę indywidualności i zbiorowości, habitusu i tożsamości, wyobrażeń i ideologii, a w konsekwencji umożliwia również „uchwycenie przeżywanego doświadczenia, emocjonalności i percepcji”, prześledzenie społeczno-kulturowej „interaktywności zarówno na małą, jak i dużą skalę”, spojrzenie na relacje pomiędzy „zażyłością, władzą i tym, co społeczne i polityczne” $\mathrm{w}$ „nieustannie zmieniających się warunkach życia społecznego" i bez redukowania znaczenia jednych kontekstów kosztem innych (Skoggard, Waterston, 2015: 117).

Tym samym codzienność i jej powtarzalność przesiąknięta jest afektywnością, w ramach której pojawiają się różnego rodzaju „dostrojenia” będące sprawczym sposobem radzenia sobie z określonymi warunkami. Dostrojenie dotyczy bowiem dopasowywania czy też adaptowania „zmysłów, praktyk i wyobrażeń do potencjalnych sposobów życia lub też przeżywanych rzeczy" (Stewart 2011: 452). Dostrajanie się jest więc sprawczym radzeniem sobie z „afektywnymi stanami” (Vigh 2018), którymi przesiąknięta jest codzienność. Stany te są zróżnicowane i mogą być rezultatem napięć, konfliktów, wojen, trudnych warunków ekonomicznych i postępującej prekaryzacji życia, ale także i zwykłych, codziennych trosk czy dylematów. „Ładują one atmosferę” (Stewart 2011) i generują afektywne reakcje. $\mathrm{Z}$ jednej strony dostrajanie się jest rezultatem afektywnie doświadczanej codzienności; z drugiej natomiast - samo w sobie jest ono afektywne (Stewart 2011).

Zatem, prowadząc intensywnie mobilne życie, pracownicy budowlani nieustannie dostrajają się do zmieniających się okoliczności (miejsca, praca, współpracownicy), jednocześnie nadając znaczenia $\mathrm{w}$ ten sposób doświadczanym momentom i sytuacjom. Dostrajanie się jest oczywiście zróżnicowane i zależne zarówno od indywidualnych doświadczeń, jak i od konkretnego uwarunkowania społecznego, kulturowego, ekonomicznego i politycznego. Niemniej sam kontekst dostrajania jest sprawczością, która może dotyczyć wytwarzania różnicy czy też 
podejmowania próby zmian przeżywanych okoliczności. W przypadku pracowników budowlanych początkowo pasywna powtarzalność z czasem ujawnia jednak sprawcze konteksty afektywnego dostrajania się zarówno do strukturalnego kontekstu ekonomii politycznej, jak i doświadczanych w danym momencie przestrzeni i warunków pracy (zob. Pawlak 2019).

Po pierwsze, afektywnym dostrojeniem jest sama mobilność. Większość pracowników budowlanych, z którymi rozmawiałem na terenie elektrowni, była niezwykle doświadczonymi migrantami, którzy pracowali na różnych budowach w Polsce (Wrocław, Szczecin, Warszawa), ale także i w innych krajach europejskich (Niemcy, Belgia, Wielka Brytania). Dla wielu z nich długotrwała mobilność, przemieszczanie się pomiędzy różnymi lokalnościami i krótkoterminowe umowy o pracę stanowiły podstawową strategię utrzymania siebie i swoich rodzin. Przenosząc się więc z miejsca na miejsce, pracownicy budowlani wytworzyli specyficzne sposoby tymczasowego „osadzania się” w różnych warunkach i „zamieszkiwania” różnych lokalności. Jednocześnie ich „domem” pozostawały miejscowości, z których pochodzą i gdzie na co dzień żyją ich rodziny i przyjaciele. Mobilność stanowi więc dla nich pewnego rodzaju zasób, a jej wykorzystywanie jest przykładem sprawczego korzystania $\mathrm{z}$ istniejących możliwości. Pracownicy budowlani wykorzystują bowiem możliwość przemieszczania się pomiędzy różnymi „placami budowy" w celu maksymalizacji swych zysków. Jest to mobilność niezwykle intensywna, w której czas i przestrzeń stają się relatywne i doświadczane w sposób niejednoznaczny, i której afektywność może wywoływać frustrację związaną ze strukturalnymi zależnościami i potrzebą podążania za pracą (zob. Pawlak 2019).

Po drugie, w strategiach pracowników budowlanych można zaobserwować pewnego rodzaju tymczasowość, która pozwala na relatywną łatwość adaptowania się do nowych miejsc pracy. Tymczasowość zakłada tu specyficzne doświadczanie temporalności w sytuacji bycia mobilnym i chwilowego „zamieszkiwania” w danej lokalności. Istnieje oczywiście złożona zależność pomiędzy indywidualnym a zbiorowym doświadczaniem czasu, w ramach której wzajemnie przecinają się różne rytmy codzienności oraz skale globalnych, narodowych i lokalnych powiązań (zob. Griffiths i in. 2013; Wallman 2004). W przypadku pracowników budowlanych pojawia się jednak również poczucie czasu, które można określić jako bycie „W międzyczasie”. Jest to kontekst obejmujący zróżnicowane rytmy czasu „instytucjonalnego" (harmonogram pracy i przydzielone zadania), „czekania” (na ofertę pracy, na kolejną zmianę, na koniec pracy, na weekendowy wyjazd do rodzinnego miasta) i „mijającego" czasu (podczas pracy, po pracy, pomiędzy pracami) (por. Griffiths i in. 2013). „W międzyczasie” definiuje więc niejako codzienność pracowników budowlanych. Z jednej strony są oni „w międzyczasie”, kiedy czekają na nowe kontrakty i oferty pracy na różnych budowach; $z$ drugiej natomiast sama praca i codzienność pobytu w miejscu, w którym pracują, również sprowadzają się do temporalnych aspektów bycia „w międzyczasie”. Mówiąc inaczej, intensyw- 
na mobilność ekonomiczna wprowadza kontekst tymczasowości, który dla pracowników budowlanych staje się strategią radzenia sobie w warunkach pracy.

Po trzecie, pracownicy budowlani wykazują się dużą elastycznością, która jest rezultatem mobilnych strategii ekonomicznych i poczucia tymczasowości. Tego rodzaju dostrojenie jest silnie osadzone w neoliberalnym „imaginarium”, w ramach którego wytworzone zostały nowe podmiotowości, często określane w kategoriach „przedsiębiorczego ja”, „elastycznych obywateli”, „elastycznych ciał” czy też tożsamościowych „minikorporacji” (Makovicky 2014: 7). Ludzie muszą być przygotowani na wszelkie zmiany i nieustanne podejmowanie ryzyka w rozmaitych kwestiach - nie tylko związanych z pracą, ale także z życiem w ogóle. Człowiek, który funkcjonuje w elastycznym kapitalizmie, nie jest już przywiązany do jednego miejsca, a jego kariera zawodowa nie jest związana tylko i wyłącznie ze sztywnymi ramami biurokracji i rutyny (Sennett 2006: 55-80). Co ciekawe, elastyczność jest wręcz fetyszyzowana przez ideologię neoliberalną w myśl zasady, że brak stałego zatrudnienia nie jest problemem, ale raczej szansą, możliwością i otwarciem się na to, co nowe, a co wcześniej było poza zasięgiem zbyt skostniałych stabilnych reguł życia. Pojawia się jednak pewien paradoks w praktykowaniu tego rodzaju sprawczej elastyczności przez pracowników budowlanych. Mimo że ich strategie ekonomiczne są silnie osadzone w neoliberalnych tożsamościach opartych na kalkulacji zysku, to w dyskursie publicznym często bywają pomijani jako agenci przystosowani do warunków kapitalistycznych. Co więcej, często są oni wykluczani czy wręcz patologizowani w głównym nurcie debat o rozwoju i nowoczesności, które często „naturalizują” kapitalistyczne „myślenie” i „działanie”. Jak zauważa Michał Buchowski:

$\mathrm{w}$ tworzonych przez elity dominujących dyskursach obecnych w środkach masowego przekazu i analizach naukowych to „natura podporządkowanych” - właściwa robotnikom, rolnikom i mieszkańcom wsi - jest przyczyną ich własnej zdegradowanej sytuacji materialnej i zarazem problemów dla całego społeczeństwa (Buchowski 2008: 100).

Według Buchowskiego proces ten jest rezultatem specyficznej racjonalizacji i wyjaśniania coraz bardziej widocznych różnic klasowych i nierówności społecznych przy pomocy soczewek „orientalizmu”, gdzie w kategorię Inności wrzuca się wszystkich tych, którzy rzekomo nie potrafią zaadaptować się do rzeczywistości kapitalistycznej. Tego rodzaju wyobrażenie często projektowane jest na zesencjalizowaną klasę robotniczą, pozbawiając ją jednocześnie jakichkolwiek form sprawczości (por. także Rakowski 2009).

I w końcu, po czwarte, afektywnym „dostrojeniem” jest również obojętność pracowników budowlanych względem kontekstów społecznych, kulturowych, ekonomicznych i politycznych lokalności, w których przebywają. Mówiąc inaczej, podczas wielu naszych rozmów na temat doświadczeń pracy w różnych miejscach w Polsce moi informatorzy rzadko używali nazw miast i miejscowości, w których tymczasowo przebywali. Znacznie częściej natomiast pojawiały się nazwy struk- 
tur przez nich budowanych. Ich narracja zdominowana więc była przez określenia typu „jak budowaliśmy most...” czy też „kiedy robiliśmy autostradę...”. Tego rodzaju określenia lokalności, w których w przeszłości pracowali, pozwala na łatwiejsze przystosowanie się do danych warunków i pokazuje, że kontekst „tu” i „teraz" jest obojętny. Istotna jest praca, będąca podstawą mobilnych strategii ekonomicznych. Obojętność jest afektywnym „dostrajaniem” się względem tego, "Co się dzieje” lub „co może się zdarzyć” (Stewart 2011: 452). Bycie „obojętnym” zakłada specyficzny rodzaj „bezruchu” czy też „spokoju” (stillness) w sytuacji mobilności, a tym samym implikuje formę sprawczości, której celem jest „podtrzymywanie" znanego i familiarnego życia w kontekście doświadczania innych lokalności, zmian i nieprzewidywalności (Stewart 2005).

Intensywną mobilność, tymczasowość, elastyczność i obojętność doświadczanej przestrzeni przez moich informatorów można zilustrować za pomocą specyficznego idiomu, który usłyszałem pewnego wieczoru, grając w kilka osób w bilard. Obok stołu bilardowego stały trzy maszyny „jednorękich bandytów”, które cieszyły się dużą popularnością wśród pracowników budowlanych. Nawet jeśli ktoś nie grał, to z zaciekawieniem oglądał, jak grają inni. Wokół maszyn zawsze stało od kilku do kilkunastu osób, które zabijały czas pomiędzy zmianami w pracy. Tego wieczoru do jednego z grających na maszynach zadzwoniła żona, ale ich rozmowa trwała krótko, ponieważ on postanowił ją zakończyć, wykrzykując nieco zirytowany „mam wyjechane”. Było to wówczas dosłowne i metaforyczne określenie kontekstu, w którym się on znajdował - „był wyjechany” w sensie fizycznej mobilności i bycia $z$ dala od domu, jak również „miał wyjechane”, a więc był tymczasowy, elastyczny i obojętny w stosunku do tego, co dzieje się wokół. Idiom ten jest ciekawym przykładem negocjowania pozycji pracowników budowlanych w kontekście ich mobilnych strategii ekonomicznych, który ukazuje sprawcze konteksty afektywnego dostrajania się w danej sytuacji mobilności.

\section{Podsumowanie}

Współczesna ekonomia polityczna, która oparta jest na neoliberalnych formach kapitalizmu, nie tylko przeobraża relacje pracy, ale również w znaczący sposób wpływa na codzienność pracowników budowlanych. Ich mobilność, tymczasowość, elastyczność i obojętność stanowią przykłady dostrajania się do nowych miejsc, ludzi i zależności. Jest to związane z afektywnym doświadczaniem i negocjowaniem kontekstów współczesności, która kształtowana jest zarówno przez lo-

6 Tego rodzaju „obojętność” można zaobserwować również w kontekście sporu politycznego dotyczącego administracyjnych zmian granic gminy i przyłączenia części wsi do miasta Opola. Dla pracowników budowlanych był to mało istotny kontekst, którego raczej nie poruszano podczas rozmów w hotelu. Nic w tym jednak dziwnego, skoro ich pobyt w gminie miał charakter „zadaniowy” i „tymczasowy”. 
kalnie „umiejscowione” praktyki społeczne i znaczenia kulturowe, jak i globalnie „wymiejscowione” zależności i uwikłania. Mówiąc inaczej, mobilność, tymczasowość, elastyczność i obojętność są strategiami pokazującymi sprawczość pracowników budowlanych, a więc ich pragmatyczne działania i kreatywne praktykowanie codzienności w nieustannie zmieniających się okolicznościach.

Co więcej, mobilne strategie ekonomiczne pracowników budowlanych stanowią również punkt wyjścia do rozważań nad samą kategorią sprawczości w czasach późnego industrializmu. Afektywne „dostrojenia” wskazują bowiem na istniejące zależności pomiędzy przeszłymi doświadczeniami, teraźniejszością dynamiką zdarzeń a wyobrażeniami na temat przyszłości. Jak zauważa Kirsten Hastrup (2005: 11), negocjujemy i „odgrywamy nasze bycie-w-świecie” w działaniu, opierając się zarówno na antecedencji, jak i antycypacji. Aby więc „wyjaśnić, jak działa świat”, musimy tworzyć i eksplorować „nowe powiązania pomiędzy wyobrażeniami a faktami społecznymi" (Hastrup 2005: 16). To zatem nie tylko zhabituowana przeszłość nadaje formę i znaczenia sprawczym działaniom w naszej codzienności. Równie istotną rolę odgrywa kontekst antycypowania, wyobrażania i spekulowania na temat przyszłości, który coraz częściej towarzyszy nam w codziennych działaniach. W późnym industrializmie przeszłość i przyszłość są bowiem wzajemnie sprzężone, nadając znaczenia temu, co „tu i teraz”. To czas ryzyka, niepewności, niestabilności czy też zwielokrotnionych kryzysów, których negocjowanie $\mathrm{w}$ lokalnie osadzonych codziennościach ukazuje rozmaite formy sprawczości.

\section{Bibliografia}

Amit V. (ed.)

2000 Constructing the Field: Ethnographic Fieldwork in the Contemporary World, London-New York.

Bauman Z.

2006 Płynna nowoczesność, przeł. T. Kunz, Kraków.

Beck U.

2002 Społeczeństwo ryzyka. W drodze do innej nowoczesności, przeł. S. Cieśla, Warszawa.

Buchowski M.

2008 Widmo orientalizmu w Europie. Od egzotycznego Innego do napiętnowanego swojego, przeł. M. Golinczak, „Recykling Idei”, nr 10, s. 98-107.

Clough P.T., Halley J. (eds.)

2007 The Affective Turn: Theorizing the Social, Durham-London.

Eriksen T.H.

2016 Overheating: An Anthropology of Accelerated Change, London.

Faubion J.D., Marcus G.E. (eds.)

2009 Fieldwork Is Not What It Used to Be Learning Anthropology's Method in a Time of Transition, New York. 
Fortun K.

2001 Advocacy after Bhopal: Environmentalism, Disaster, New Global Orders, Chicago. 2012 Ethnography in Late Industrialism, „Cultural Anthropology”, nr 3 (27), s. 446-464. 2014 From Latour to Late Industrialism, „Hau: Journal of Ethnographic Theory”, nr 4 (1), s. 309-329.

Giddens A.

2007 Nowoczesność i tożsamość. „Ja” i społeczeństwo w późnej nowoczesności, przeł. A. Szulżycka, Warszawa.

Griffiths M., Rogers A., Anderson B.

2013 Migration, Time and Temporalities: Review and Prospect, Oxford.

Gupta A., Ferguson J. (ed.)

1997a Culture, Power, Place: Explorations in Critical Anthropology, Durham-London.

Gupta A., Ferguson J.

1997b Discipline and Practice: The "Field" as Site, Method, and Location in Anthropology, w: A. Gupta, J. Ferguson (eds.), Anthropological Locations: Boundaries and Grounds of a Field Science, Berkley-Los Angeles-London, s. 1-46 .

Harvey D.

2008 Neoliberalizm. Historia katastrofy, przeł. J.P. Listwan, Warszawa.

Hastrup K.

2005 Performing the World: Agency, Anticipation and Creativity, „The Cambridge Journal of Anthropology", nr 25 (2), s. 5-19.

Heffner K., Rauziński R.

2012 Ewolucja regionu migracyjnego w Polsce (na przykładzie Śląska Opolskiego), w: U. Zagóra-Jonszta, A. Skórska (red.), Problemy współczesnej ekonomii, Katowice, s. $43-62$.

Heffner K., Solga B.

2009 Współczesna mobilność Polaków a regionalny kontekst procesów migracyjnych, w: B. Solga (red.), Zmieniajaca się rola migracji w rozwoju regionalnym, Opole, s. 15-33. Holmes D.R., Marcus G.E.

2006 Fast Capitalism: Para-Ethnography and the Rise of the Symbolic Analyst, w: M.S. Fisher, G. Downey (eds.), Frontiers of Capital: Ethnographic Reflections on the New Economy, Durham, s. 33-57.

Illouz E.

2010 Uczucia $w$ dobie kapitalizmu, przeł. Z. Simbierowicz, Warszawa.

Jończy R.

2003 Migracje zarobkowe ludności autochtonicznej z województwa opolskiego. Studium ekonomicznych determinant $i$ konsekwencji, Opole.

2006 Wpływ migracji zagranicznych na dysharmonie rozwoju województwa opolskiego (ze szczególnym uwzględnieniem rynku pracy), Opole.

2010 Migracje zagraniczne z obszarów wiejskich województwa opolskiego po akcesji Polski do Unii Europejskiej: wybrane aspekty ekonomiczne i demograficzne, OpoleWrocław.

Larkin B.

2013 The Politics and Poetics of Infrastructure, „Annual Review of Anthropology”, nr 42, s. 327-343.

Lash S., Urry J.

1987 The End of Organized Capitalism, Madison. 
Lesiuk W., Rauziński R., Sołdra-Gwiżdż T. (red.) 2000 Między przeszłością a przyszłością. Elektrownia „Opole” jako czynnik zmiany spoŁecznej, Opole.

Lutz C.

2017 What Matters, „Cultural Anthropology”, nr 32 (2), s. 181-191.

Łuszczewska B. (red.)

1993 Elektrownia „Opole” a środowisko społeczne, Opole.

Makovicky N.

2014 Introduction: Me, Inc.? Untangling Neoliberalism, Personhood, and Postsocialism, w: Neoliberalism, Personhood, and Postsocialism: Enterprising Selves in Changing Economies, red. N. Makovicky, Farnham-Burlington, s. 1-16.

Marcus G.E.

1986 Contemporary Problems of Ethnography in the Modern World System, w: J. Clifford, G.E. Marcus (eds.), Writing Culture: Politics and Poetics of Ethnography, Berkley, s. $165-193$.

Olwig K.F., Hastrup K. (eds.), 1997 Siting Culture: The Shifting Anthropological Object, London-New York.

Olwig K.F., Sørensen N.N. (eds.)

2002 Work and Migration. Life and Livelihoods in a Globalizing World, London-New York.

Ong A.

2006 Neoliberalism as Exception: Mutations in Citizenship and Sovereignty, DurhamLondon.

Ong A., Collier S. (eds.), 2005 Global Assamblages: Technology, Politics, and Ethics as Anthropological Problems, Oxford.

Pawlak M.

2018 Zawstydzona tożsamość. Emocje, ideologie $i$ władza $w \dot{z} y c i u$ polskich migrantów $w$ Norwegii, Kraków.

2019 Mobile Livelihood: Temporariness, Indifference and Flexibile Subjectivities in the Industrial Site, w: P. Sklanik (red.), Mutual Impact: Conflict, Tension and Cooperation in Opole Silesia, Wrocław, s. 101-123.

Rabinow P.

2011 The Accompaniment: Assembling the Contemporary, Chicago.

Rabinow P., Marcus G.E., Faubion J.D., Rees T.

2008 Designs for an Anthropology of the Contemporary, Durham.

Rakowski T.

2009 Łowcy, zbieracze, praktycy niemocy. Etnografia człowieka zdegradowanego, Gdańsk.

Rauziński R. (red.)

1988 Wpływ elektrowni „Opole” na przeobrażenia spoleczno-ekonomiczne gminy i rejonu Dobrzeń Wielki, Opole.

Rosik-Dulewska C., Kusza G. (red.)

2009 Budowa bloków 5 i 6 w PGE Elektrowni Opole SA - aspekty gospodarcze, środowiskowe i społeczne, Opole.

Samimian-Darash L., Rabinow P. (eds.)

2015 Modes of Uncertainty: Anthropological Cases, Chicago. 
Sennett R.

2006 Korozja charakteru. Osobiste konsekwencje pracy w nowym kapitalizmie, przeł.

J. Dzierzgowski, Ł. Mikołajewski, Warszawa.

2010 Kultura nowego kapitalizmu, przeł. G. Brzozowski, K. Osłowski, Warszawa.

Skoggard I., Waterston A.

2015 Introduction: Toward an Anthropology of Affect and Evocative Ethnography, „Anthropology of Consciousness", nr 2 (26), s. 109-120.

Solga B. (red.)

2009 Zmieniajaca się rola migracji $w$ rozwoju regionalnym, Opole.

Sołdra-Gwiżdż T.

2009 Elektrownia „Opole” w świetle badań socjologicznych, w: C. Rosik-Dulewska, G. Kusza (red.), Budowa bloków 5 i 6 w PGE Elektrowni Opole SA - aspekty gospodarcze, środowiskowe i społeczne, Opole, s. 47-70.

Stewart K.

2005 Trauma Time: A Still Life, w: D. Rosenberg, S. Harding (eds.), Histories of the Future, Durham-London, s. 321-339.

2007 Ordinary Affects, Durham-London.

2011 Atmospheric Attunements, „Environment and Planning, D: Society and Space”, nr 29, s. 445-453.

Svašek M.

2005 Emotions in Anthropology, w: K. Milton, M. Svašek (eds.), Mixed Emotions: Anthropological Studies of Feeling, Oxford, s. 1-24.

2012 Emotions and Human Mobility: Key Concerns, w: M. Svašek (ed.), Emotions and Human Mobility: Ethnographies of Movement, London-New York, s. 1-16.

Tsing A.

2002 The Global Situation, w: J.X. Inda (ed.), The Anthropology of Globalization: A Reader, Oxford, s. 453-485.

Vigh H.

2018 Lives Opposed: Perceptivity and Tacticality in Conflict and Crime, „Social Anthropology", nr 26 (4), s. 487-501.

Wacquant L.

2012 Three Steps to a Historical Anthropology of Actually Existing Neoliberalism, „Social Anthropology", nr 1 (20), s. 66-79.

Wallman S.

2004 The Hazards of Overemployment: What Do Chief Executives and Housewives Have in Common?, w: A. Procoli (ed.), Workers and Narratives of Survival in Europe: The Management of Precariousness at the End of the Twentieth Century, New York, s. 15-30. 